\title{
PEMENANG DI ATAS PANGGUNG MELALUI MAHIR PUBLIC SPEAKING
}

\author{
Usman $^{1}$ \\ ${ }^{1}$ Dosen Ilmu Komunikasi Fakultas Dakwah dan Komunikasi \\ Universitas Islam Negeri Sultan Syarif Kasim Riau \\ Jl. HR Soebrantas Km 15 Simpangbaru, Tampan, Pekanbaru 28293 \\ email: usman@uin-suska.ac.id
}

\begin{abstract}
Abstrak
Memiliki kemampuan berbicara dihadapan publik hari ini merupakan sesuatu yang tidak bisa tawar lagi, dikarenakan tuntutan kehidupan yang semakin maju membuat public speaking menunjukan tariknya baik dunia politik dan dunia akademis apalagi dunia bisnis yang tidak terlepas dari kegiatan persentasi sehingga anda bisa membius hati pelanggan menjadi konsumen setia .kepiawanan berbicara seringkali menjadi pemenang, Indonesia misalnya Bung karno terkenal dengan orator hebat menjadi presiden Indonesia tahun 1945, Barack Obama menjadi Presiden America terpilih 2 periode, terlahir bukan berkulit putih dengan keahlian public speakingnyamenjadi pemenang diatas panggung dan pertama menjadi presiden america dari kaum berkulit hitam dan masih banyak tokoh-tokoh lainnya yang menjadikan public speaking menjadi kendaraan dalam mencapai karirnya.Mahir dalam public speaking bukan hanya sebagai hobi namun juga dapat mendulang rupiah seperti Mario Teguh seorang motivator yang terkenal dengan salam super mampu membius audiens, Ongky Hojanto dibayar Rp 20.000.000 untuk 3 jam seminar, Tung Desem Waringin di bayar Rp. 100.000.000 untuk 3 jam seminar, Anthony Robbins di bayar US\$1.000.000 untuk 3 jam seminar. Kemampuan Public speaking adalah tuntutan hampir semua profesi guru, dosen, manejer, pendakwah, instruktur, narasumber, penyiar,presenter, mc/pembawa acara, politikus dan pembisnis.
\end{abstract}

Kata kunci : Menjadi pemenang, mahir public speaking

\section{A. Pendahuluan}

Kemampuan berbicara tidaklah semudah yang dibayangkan seperti halnya membalikan telapak tangan sehingga sering mendengar ungkapan bahwa begitu sulit berbicara dihadapan orang banyak walaupun dihadapan teman-teman sejawat yang sudah setiap hari berjumpa, dari hal yang simpel seperti menggakat tangan untuk bertanya bahkan untuk memberi pendapat saja terasa sangat berat apalagi sampai merangkai ungkapan kalimat terindah penuh makna yang diawali dari proses membuat konsep menguasai materi bahkan sampai pada persiapan tanpil dihadapan audiens, bukan itu saja konsep yang tadinya sudah dipersiapkan dengan matang, ternyata ketika tampil mulai terasa badan kaku, mulut seakan terkunci susah untuk berbicara tidak tau harus dimulai darimana bahkan semua bisa lupa dengan apa yang hendak disampaikan. Hal seperti ini sering terjadi bahkan setiap pembicara fomula hampir mengalami hal yang sama yaitu sering disebut demam panggung. Pada prinsipnya semua dalam diri kita sudah diberi kekuatan oleh Allah yang maha kuasa, tuhan yang maha dahsyat untuk menghadapi segala problematika kehidupan bahkan termasuk juga mampu beribicara dengan baik dan menghilangkan rasa gugup dalam penampilan oleh karena itu dibutuhkan 
kemampuan atau teknik berbicara dihadapan umum, inilah yang disebut "Public Speaking " kepiawaian seseorang berbicara dihadapan umum tentunya memerlukan keahlian yaitu mampu merangkai kata-kata sehingga indah didengar dan membius audiens, sebagai pendengar selalu menginginkan dan menantikan setiap ucapan dari anda karena ucapan anda merupakan bius dari harapan yang selama ini audiens inginkan, seperti seorang pengusaha konter pulsa tentunya punya cara tersendiri untuk meraih perhatian konsumen agar menjadi konsumen tetap dan tidak berpindah kelain hati dan menjadi konsumen tetap sehingga anda menjadi pemenang diatas panggung melalui mahir public speaking.

Proses menjadi seorang mahir public speaker yang handal itu antara lain harus menguasai materi dengan sangat baik tanpa harus bergantung pada slide bahan presentasi (kalau perlu sampai 200\%, karena kalau seseorang mengalami nervous saat bicara, pasti performa dari presentasi tersebut akan menurun hingga setengahnya), berbicara dengan pengucapan yang jelas dan nada bicara yang variatif disertai bahasa tubuh yang menunjang (kontak mata, dll), berbicara dengan sistematis dan ringkas, dan hal-hal teknis lainnya yang sudah biasa kita baca dalam artikel atau buku yang mengulas tentang seni public speaking.

\section{B. Pembahasan}

\section{Pemenang diatas panggung}

Menjadi seoarang pemenang diatass panggung sangat banyak didambakan oleh seorang pembicara tapi tentunya tidak semua orang mampu mendapatkannya, maka mestilah dengan dengan usaha dan proses yang begitu panjang sehingga bisa menjadi pembicara yang memukau audiens. Pada prinsipnya jika seseorang memiliki kemauan dan kesungguhan dalam mempelajarinya maka untuk itu perlu sekali mengasah kemampuan dalam memalakukan Kegiatan berbicar di depan publik adalah kegiatan yang selalu menyertai seseorang yang bekerja di bidang yang berkaitan dengan pendidikan, seperti pendidik, instruktur, penceramah, atau guide dari suatu objek wisata, ini menjadi penting bagi seorang yang berprofesi tersebut untuk memiliki kompetensi berbicara di depan publik, agar dapat mendukung kelancaraan tugasnya berbicara dengan satu dua orang hal yang mudah, tetapi berbicara di depan puluhan orang perlu kiat-kiat khusus untuk melakukannya

Seorang yang tampil diatas pangung mesti mahir teknik-teknik untuk berbicara di depan banyak orang, maka setiap kata dan setiap kalimat harus tersusun dengan baik dengan alur berpikir yang benar dan sistematis. Pikiran yang jermih, mood (suasana hati) yang baik, dan kepiawaian merangkai kalimat merupakan modal utama seseorang dapat berbicara lancar dan berhasil di depan audien. Selain itu juga diperlukan kecerdasan berpikir dan kecekatan menalar agar dapat memberikan argumen-argumen jitu dan meyakinkan kepada audien. Pada kenyataannya, sebagian pendidik atau instruktur tidak dibekali cara berbicara yang baik dan menarik. Penguasaan pangung tidak terlepas dari kontribusi peranan dari ilmu komunikasi sebagai cikal bakal dari ilmu retorika yang disebut juga dengan seni bicara yang menekankan pada kemampuan berpidato, dimana tujuan utamanya khalayak bisa tertarik perhatiannya dan terbujuk. Ada beberapa orang yang mengartikan retorika sebagai public speaking atau pidato di depan umum berkaitan dengan hal itu, maka jika ingin menjadi pembicara yang handal dan sukses selain bakat, juga dapat dikembangkan dengan berlatih mengasah kemampuan public speaking.

Menjadi pemenang diatas panggung maka dapat dilakukan sebagai berikut:

1. Latihan terus menerus

Mengenal pangung dari forum yang terkeci sampai yang besar memerlukan ketekunan dan kesungguhan artinya perlu melakukan pelatihan public speaking yan bersipat kontiniu sehingga dapat menghilangkan rasa gugup atau demam panggung karena sudah terbiasa dengan latihan tersebut.

2. Tambah jam terbang 
Perlu sekali bagi seseorang yang ingin terkenal sukses berbicara diatas pangung atau mimbar untuk meningkatkan jam terbang, kemampuan public speaking sangat mudah untuk masuk keberbagai lini kehidupan sehingga banyak tempat untuk tampil karena kemahiran public speaking dibutuhkan banyak bidang seperti bidang politi, ceramah, bisnis, pariwisata terutama dalam memberikan motivasi kepada khalayak misalnya karyawan suatu perusahaan, jamaah pengajian maupun sosialisasi program kepada masyarakat.

3. Bangun relasi

Seiring perkembangan zaman akhir ini maka relasi merupakan hal yang tak bisa dipisahkan dalam kehidupan apalagi didunia public speaking karena dengan adanya relasi maka akan membuka banyak peluang untuk mendapatkan kebutuhan serta meraih yang diinginkan, dalam hal penguasaan panggung sebagai wadah berbicara maka membangun relasi sangat bahkan perlu mendapatkan perhatian khusus sehingga relasi yang dibangun bisa mendatang

Kan peluang seperti tampil bicara diberbagai panggung atau mimbar bahkan dimedia massa.

\section{Menjadi pembicara yang menyenangkan}

Harapan menjadi seorang yang terkenal bahkan menjadi pembicara yang menyenangkan adalah bukan hal yang mudah menjadi seorang pembicara yang menyenagkan dan bisa membuat audience benar-benar menyimak apa yang kita bicarakan, tapi hal itu bukan tidak mungkin dilakukan. Sambil terus mengasah kemampuan teknis kita dalan melakukan presentasi atau berbicara didepan umum, kita bisa sering-sering mempraktikkan ilmu menyenangkan orang, pada orang-orang di sekeliling kita dengan antara lain memberi senyuman, sering memuji dan memberi perhatian, sehingga hal-hall tersebut bisa menjadi suatu yang otomatis juga diterapkan pada saat kita berbicara didepan umum.

Menjadi pembicara yang menyenagkan merupakan langkah awal yang sangat penting dilakukan, agar probabilitas audience mau mendengarkan dan menyerap apa yang kita bicarakan semakin besar. Menurut Lilly Walters, seorang public speaker ternama di Amerika, bahwa kesuksesan sebuah presentasi tidak ternilai berdasarkan pada pengetahuan yang disampaikan oleh pembicara, tetapi pada apa yang diterima atau ditangkkap oleh audiens. ${ }^{1}$ Kemampuan dalam menguasai audien merupakan bagian terpenting dalam public speaking sehingga seorang pembicara dapat masuk dalam tataran uadiens manapun selain itu pembicara yang menyenangkan biasanya dalam menyampaikan materi tidak terkaku pada satu titik akan tetapi menjadi pembicara menyenangkan mampu memainkan humor sebagai bentuk penguasaan audiens.

\section{Bangun hubungan atau rapport dengan audience}

Untuk menarik perhatian dengan audience, kita harus berusaha membangun suatu 'hubungan' dengan mereka dari saat kita mulai berbicara. Tidak mudah memang, tapi kita bisa mulai dengan, misalnya, mengapresiasi usaha mereka untuk hadir di tempat tepat waktu padahal traffic menuju tempat tersebut biasanya selalu macet. Kemudian carilah kesamaan antara kita dengan audience. Jika kita berbicara di depan para dokter, maka kita bisa mengawali presentasi kita dengan bercerita tentang pengalaman orang di sekitar kita yang pernah menderita suatu penyakit, dan kaitkan hal tersebut dengan pentingnya peran seorang dokter dalam situasi seperti itu. kemudian untuk member pujian pada audience, misalnya jika mereka bisa melontarkan pertanyaan yang menarik pada sesi Tanya jawab. Manusia pada

${ }^{1}$ Sameto, H. (2006). Kiat Sukses Mengolah Komunikasi. Jakarta: Puspa Sawara. 
dasarnya senang dipuji, jika mereka merasa senang, umumnya mereka akan lebih memperhatikan apa yang kita bicarakan. Akan lebih baik kalau kita bisa mendapatkan informasi tentang siapa audience kita, sehingga kita bisa mempersiapkan bahasan seperti apa yang bisa dipakai untuk membuka presentasi, gaya bahasa apa yang akan kita gunakan, dan lain-lain. Jika mayoritas audience kita adalah generasi '140 karakter' ataug enerasi yang sanga takrab dengan socmed, maka kita harus menggunakan gaya bahasa yang ringkasdan to-thepoint. Jika audience merasa bahwa kita sebagai pembicara memiliki suatu 'kesamaan' dengan mereka, hubungan antar pembicara dan audience pun bisa mudah terbentu, audience akan lebih senang dan tertarik dengan apa yang akan kita bahas jika dari awal mereka juga merasa dihargai dan dilibatkan, karena public speaking itu merupakan komunikasi yang seyogyanya juga berjalan dua arah.

\section{Public speaking}

Menurut David Zarefsky, dalam public speaking strategic for success, "Public speaking is a continous communication process in which massages and listeners." Public speaking adalah sebuah proses komunikasi yang berkelanjutan dimana pesan dan lambang bersikulasi ulang secara terus menerus antara pembicara dengan pendengarnya ${ }^{2}$.

Menurut Gunadi dalam himpunan istilah komunikasi, Public speaking adalah sebuah bentuk komunikasi yang dilakukan secara lisan tentang sesuatu hal atau topik dihadapan banyak orang. Tujuannya adalah untuk mempengaruhi, mengubah opini, mengajar, mendidik memberikan penjelasan serta memberikan informasi kepada masyarakat tertentu pada suatu tempat tertentu. ${ }^{3}$ Banyak tokoh yang terkenal dan menorehkan sejarah dunia, bukan karena kekayaan atau jabatantiknya, melainkan karena kemampuan mereka dalam hal menginspirasijutaan orang. Kemampuan inilah yang dinamakan dengan public speaking.) Public speaking adalah tatacara melakukan berbicara didepan umum dan terancana dengan tujuan tertentu. Public speaking juga disebut dengan berbicara depan public yaitu seni berbicara dihadapan tentang suatu hal atau topik secara lisan, dengan tujuan mempengaruhi, mengajak, membujuk, mendidik, mengubah opini, memberikan penjelasan\& informasi. Pada intinya public speaking adalah kemampuan/teknik berbicara dihadapan umum.

Public speaking memiliki tujua yaitu menyampaikan pesan atau ide kepada publik dengan metode yang sesuai sehingga publik bisa memahami pesan atau ide, dan kemudian memperoleh manfaat dari pesan tersebut. menyampaikan pesannya.

\section{Perlunya cara dalam public speaking}

Seorang public speaker dituntut untuk mampu memilih cara maupun metode yang tepat sehingga penampilan public speaking mendapat sambutan hangat dimata uadiens, beberapa cara yang bisa diterapkan seperti :

a. Impromptu speech, artinya seseorang untuk menyampaikan gagasannya tidak melakukan banyak persiapan. Dengan kata lain seorang public speaking bekerja secara mendadak.

b. Manuscript speech, artinya seseorang dapat melihat naskah saat menyampaikan gagasannya.

c. Extemporaneous speech, artinya seseorang tanpa menggunakan naskah dapat menyampaikan gagasannya dengan lebih informatif dan komunikatif. Dalam hal ini pembicara bebas berimprovisasi. ${ }^{4}$.

\footnotetext{
${ }^{2}$ D.Darmayanti, 1 Jam mahir public speaking untuk Guru dan Dosen (Jogyakarta: pinang merah publisher, 2013), hlm 9

${ }^{3}$ Ibid. 10

${ }^{4}$ Elly Juniarti dan pramana, General Public Speaking (Jakarta: Public speaking school,2006) hlm.3
} 
Cara yang tepat pastinya memiliki hasil yang menyenangkan serta memuaskan hati audiens,untuk itu mesti memahami serta menguasai metode dalam menyampaiakan materi sehingga dapat mendatangkan kepuasan pada uadiens yang berujung pada kenyamanan serta memberikan kesan yang baik terhadap pembicara.

\section{Saatnya Mahir Public Speaking}

Profesi sebagai seorang public speaker sangat banyak diminati oleh orang namun menjadi seorang yang mahir public speaking harus mempuyai persiapan yang optimal, kepercayaan diri yang tinggi, penguasaan kata-kata yang baik, kontak mata dan gerak tubuh yang baik, dan kemampuan mengendalikan audiens sebagai berikut:

\section{a. Anda bisa}

Semangat yang kuat biasanya diieingi dengan usaha serta tekat yang kuat sehingga anda bisa inilah yang disebut dengan rasa percaya diri yang sangat penting, karena ini menjadi kekuatan saat kita tampil dihadapan umum, berpiir positif tentunya akan membantu kita untuk menimbulkan rasa percara diri jangan sampai sebaliknya, ketakutan itu perlahan-lahan akan hilang apabila kita sering mencoba melakukan hal yang kita takutkan, lalu membuat kesalahan, dan kemudian dengan cermat mengambil pelajaran dari setiap pengalaman yang didapatkan. Seperti yang dinyatakan oleh Dale Carnegle, 2006, bahwa cara tercepat dan terbaik untuk mengalahkan rasa takut adalah dengan melakukan apa yang kita takutkan ${ }^{5}$.

\section{b. hadirkan persiapan}

Sehebat apapun bakat dan pengalaman yang anda miliki, persiapan menyumbang 90\% dari keberhasilan berbicara anda. .

Menjadi tugas seorang public speaker adalah menyampaikan ide kepada audiens dan ide tersebut berpotensi untuk mempengaruhi tindakan audiens. Untuk itu, sangat diperlukan persiapan yang optimal sebelum melakukan presentasi di depan audiens.

1. Pengenalan Audiens

Pengenalan audiens dapat membekali kita dalam memilih bahan, menyusun, dan menyajikannya dengan strategi yang tepat. Hal ini dikarenakan pengetahuan kita tentang publik akan menjadi konkret.

Untuk mengenali calon audiens, terdapat hal-ha umum dan khusus yang perlu diperhatikan, antara lain:

2. Hal umum seperti Jumlah audiens, rentang usia, jenis kelamin, pekerjaan, pendidikan, agama, sosial-politik dan lainnya

3. Menguasai Materi

Memahami dan menguasai materi adalah sesuatu yang harus dimiliki oleh pembicara sehingga audiens percaya dan yakin bahwa anda sangat berkopeten, Semakin banyak informasi yang dapatkan maka akan semakin baik persiapan materinya. Beberapa hal yang perlu diperhatikan yaitu: Mengetahui informasi yang dibutuhkan, Mengetahui sumber informasi, Memilih beberapa informasi dari beberapa kumpulan yang telah didapatkan, Menyusun struktur materi, Pengenalan Tempat, Penampilan Fisik. Penampilan menjadi pendukung bagi seorang pembicara, Audiens cenderung akan memberikan penilaian ketika mendapat kesan pertama yang diberikan oleh pembicara. Maka dari itu, banyak hal yang harus diperhatikan secara mendetil seperti Kerapian, kebersihan, dan kesesuaian pakaian, Kenampakan fisik saat tampil, seperti, Berdiri santai tetapi tegap, Kaki harus rapi dan terlihat sopan, keadaan tangan santai dan dapat melakukan gerakan yang seproporsional mungkin ${ }^{7}$.

\footnotetext{
${ }^{5}$ McCarty, Andrew. Mengembangkan Kepribadian dengan Berpikir Positif. 2007.

${ }^{6}$ Tantowiyahya

${ }^{7}$ Balqis khairiyah, cara pintar berbicara didepan publik. Jogjakarta 2013 hlm 95
} 
Menguasai hal-hal di atas itu tentunya butuh latihan secara rutin dan waktu yang tidak instan. apalagi bagi orang yang cenderung pendiam ataupun pemalu, kemampuan untuk merangkai kata dan mengucapkannya ataupun melakukan kontak mata dengan audience bisa merupakan tantangan tersendiri dan ini membutuhkan kesabaran dan butuh proses sehingga terbiasa dan mendapatkan hasil yang maksimal.

\section{Teknik-teknik mahir public speaking}

Untuk menjadi pemenang diatas panggung, alias pembicara yang menarik dan dapat memberikan pengaruh bagi pendengar, diperlukan teknik-teknik public speaking, antara lain:

\section{a. Teknik Ice Breaking}

1. Pembukaan yang menarik

Pembukaan adalah impresi pertama, artinya hal itu dapat mempengaruhi pandangan audiens terhadap public speaker selama presentasi. Sesingkat apapun waktu untuk melakukan presentasi, pembukaan tetaplah harus penuh kehangatan. Pembukaan dapat dilakukan dengan sebuah ilustrasi atau cerita yang sedang marak, tetapi relevan dengan topik pembiaraan. Saat menyampaikannya, tunjukkan wajah yang bersahabat, ramah, dan dekat.

2. Gunakan Joke

Humor kemungkinan mengandung resiko. Hal ini dikarenakan oleh sifatnya yang universal, sedangkan selera tiap individu sanagt personal dan individual. Tetapi, meskipun mengandung resiko humor yang baik dapat menjadi awal yang efektif untuk mencari perhatian para pendengar. Bahan-bahan joke sangat luas, karena dapat diambil dari berbagai cerita, kasus sehari-hari, gambar iklan, pengalaman orang lain, hasil riset, dan sebagainya.

\section{b. Teknik Vokal}

Penyampaian vokal yang baik didapatkan apabila seorang public speaking menguasai tiga hal berikut:

a. Pernapasan

Posisi yang baik untuk mengontrol pernapasan adalah berdiri tegak agar memberikan ruang yang lebih baik kepada paru-paru. Untuk berbicara di depan publik, diperlukan ruang suara yang solid agar dapat menyampaikan kalimat yang panjang pada volume suara yang benar.

b. Volume

Keberhasilan dalam berbicara tidak selalu ditentukan oleh kerasnya suara. Volume suara ketika berbicara di depan publik hanya sedikit lebih keras dari volume berbicara sehari-hari. Berbicara dengan volume keras hanya diperlukan pada bagian-bagian tertentu saja. Selebihnya, berbicara keras terlalu sering dapat menyebabkan tenggorokan rusak dan audiens pun bosan.

c. Ekspresi vokal

Ekspresi adalah faktor penting dalam pengolahan suara. Suara yang baik akan lebih berarti jika disertai dengan ekspresi yang tepat. Ekspresi terdiri dari tiga komponen, yaitu: 1) pitch, faktor tinggi rendahnya suara, 2) pace, faktor kecepatan berbicara, 3) phrasing,faktor kecakapan memenggal kalimat, dan disertai dengan jeda. .

\section{Tips menghilangkan rasa gugup}

Pertama, coba anda pikirkan apa manfaatnya jika anda berbicara didepan banyak orang itu. Anda coba cari apa saja keuntungan yang anda bias dapatkan kalau anda bisa berbicara dengan lancar didepan banyak orang itu. Kenapa saya memaksa anda mencari manfaat atau keuntungan? sebab itulah alasan yang mampu menguatkan pikiran anda untuk mengurangi rasa gugup dan menggantinga dengan keberanian. Orang itu mau melakukan apapun asal ada keuntungannya, benar bukan?

\footnotetext{
${ }^{8}$ Laryking . Seni berbicara. Jakarta PT. Gramedia hlm 48
} 
Kedua, rapikan pakaian anda, rapikan rambut anda, cuci bersih wajah anda. Persiapkan fisik anda, secara tampilan menjadi menarik. Perhatikan tampilan anda, apakah baju yang anda gunakan sudah bersih. Kalau menurut anda pakaian yang anda gunakan itu kurang cocok maka segera ganti dengan pakaian lain, kalau menurut anda menggunakan dasi dan jas itu membuat anda terlihat lebih rapi, maka pakailah dasi dan jas. Ketika secara tampilan anda sudah baik maka hal ini memicu pikiran bawah sadar anda untuk berbicara jauh lebih baik dari penampilan anda.

Ketiga, pastikan anda menguasi dan memahami apa yang mau anda sampaikan. Memahami materi, itu adalah cara tercepat menghilangkan gugup. Coba deh, anda gugup itu karena merasa kurang memahami materi, atau karena khawatir salah dalam menyampaikan materi, ya kan? maka anda perlu paham, ingat ya, memahami berbeda dengan menghafal.

Keempat, posisikan bahwa diri anda ingin memberi tahu "sesuatu" kepada mereka. Anda harus mengambil sikap bahwa anda memiliki sesuatu yang dibutuhkan oleh orang banyak itu, sehingga mereka pasti mendengarkan anda. Gugup terjadi, karena anda merasa bahwa anda tidak memberikan apa2,bahkan anda merasa bahwa mereka sudah tahu. Itu salah, mereka siap mendengarkan materi yang mau anda berikan, jadi berbicaralah dengan tenang.

Kelima, berjanjilah untuk menghargai usaha anda. Berjanjilah kepada diri sendiri, bahwa kalau mampu berbicara dengan tenang maka pasti memberikan hadiah kepada diri sendiri. Hadiah bisa berupa makanan atau minuman, misalnya "kalau aku nanti bicara depan orang tenang, aku mau makan mie ayam diujung jalan”. Sebuah penghargaan kepada diri sendiri itu adalah hal yang sepele tetapi sering dilupakan oleh orang.

\section{Tips tampil dengan enjoy}

Melihat pembicara yang sangat santai tentu menyenangkan serta akan mudah terjalin keakraban terhadap audiens sehingga ada kedekatan yang terjalin antara pembicara dengan audiens, untuk mewujudkan maka perlu diperhatikan sebagai berikut:

a. Rileks,tenangdanfokus

Cara mudah meningkatkan rasa percaya diri saat berbicara di depan umum yang pertama adalah rileks, tenang dan fokus. Rileks akan memberikan ketenangan pada diri Anda. Ketenangan yang Anda rasakan akan menghilangkan rasa takut atau ketakutan pada diri Anda yang pada akhirnya dapat meningkatkan fokus dan konsentrasi Anda. Dengan rileks, tenang dan fokus akan memudahkan Anda memiliki rasa percaya diri yang tinggi saat berbicara di depan umum.

b. Yakin

Cara mudah meningkatkan rasa percaya diri saat berbicara di depan umum yang kedua adalah meyakinkan diri Anda bahwa Anda bisa. Meyakinkan diri sendiri atau memberi motivasi diri sangat diperlukan untuk menumbuhkan keyakinan diri dan rasa percaya diri. Dengan meyakinkan diri sendiri akan muncul semangat dari dalam diri untuk bisa melakukan apapun dan melewati semua hambatan yang ada, termasuk meningkatkan rasa percaya diri.

c. Anggap semua orang yang Anda hadapi sebagai teman bukan musuh Cara mudah meningkatkan rasa percaya diri saat berbicara di depan umum yang ketiga adalah menganggap semua orang yang Anda hadapi sebagai teman bukan musuh. Salah satu penyebab hilangnya rasa percaya diri saat berbicara di depan umum adalah rasa takut untuk berhadapan dengan banyak orang yang jauh lebih pandai dari Anda, mencari kesalahan Anda maupun yang akan menjatuhkan Anda. Sekarang hilangkan semua pikiran negatif Anda dan anggap semua orang yang Anda hadapi sebagai teman, bukan sebagai musuh. Dengan menanamkan pikiran positif yang demikian, Anda akan dengan mudah meningkatkan rasa percaya diri Anda saat berbicara di depan umum. 
d. Kuasai semua materi dan perluas wawasan Anda

Cara mudah meningkatkan rasa percaya diri saat berbicara di depan umum yang keempat adalah menguasai semua materi dan memperluas wawasan. Dengan menguasai semua materi dan memperluas wawasan atau pengetahuan Anda, Anda memiliki persiapan yang cukup untuk berbicara di depan umum. Dengan persiapan yang cukup matang, Anda akan merasa lebih siap dan lebih percaya diri saat berbicara di depan umum ${ }^{9}$.

\section{Cara Ampuh Mengatasi Grogi}

Rasa gerogi atau yang disebut demam panggung tidak dapat hialang begitu saja apalagi bagi yang baru tampil dalam berbicara semua itu akan hialng denbgan seiring waktu sesuai dengan ketekunan dalam dalam menjalankan proses belajr adapun yang bisa lakukan sebagai berikut:

1. Persiapan

Ketika akan tampil didepan umum, hal pertama yang harus lakukan adalah mempersiapkan segala sesuatu yang dibutuhkan dengan baik. Dengan persiapan yang baik, akan lebih siap dan percaya diri. Tentu dengan begitu, siap memberikan penampilan yang terbaik.

2. Berpikir Positif

Jika ingin hasil yang baik, maka responlah setiap keadaan yang terima dengan respon yang baik juga. Maksudnya begini, rasa grogi itu bukan keadaan pertama, tapi respon dari keadaan atau kondisi yang hadapi. jika respon yang diberikan positif, maka hasilnya pun akan positif

3. power poses

Saat mengalami grogi, hindarilah postur tubuh yang lesu, loyo karena itu akan semakin memperburuk keadaan. Ketika grogi, saran yang paling baik dan ilmiah adalah tunjukkan pose yang spesifik.

4. Atur nafas

Ketika orang sedang grogi, umumnya jantung mereka berdetak lebih cepat dari biasanya dan perasaan menjadi tak menentu. Jika kondisi ini sedang rasakan saat tampil, cobalah untuk rileks dengan cara mengatur nafasmu. ketika nama dipanggil diatas panggung, jangan langsung beranjak jalan, tetaplah bersikap tenang sambil mengatur nafas dan tersenyumlah.

5.Salurkan melalui gerakan

Ketika berdiri di depan audiens, hindari posisi berdiri yang tegang, karena ini malah akan membuatmu semakin grogi. Saat berpresentasi, gunakanlah bahasa tubuh agar grogi bisa tersalurkan melalui gerakan. Contohnya seperti aktif menggunakan tangan saat berbicara ataupun sering berpindah tempat saat berbicara.

3. Berdo'a

Hal yang terpenting adalaha kesediaan hati kepada allah sebagai pencipta serta maha yang akan memberikan ketenangan serta kesuksesan dalam stiap kegiatan dan usaha yang dilakukan , maka berdoa sangat membantu dalam kegiatan public speaking.

\section{Kesimpulan}

Kemampuan berbicara di depan publik sudah sangat mutlak. Kemampuan ini mendasari kesuksesan setiap orang diberbagai bidang, menjadi pemenang diatas panggung dengan perannya sebagai pemberi pengaruh dan manfaat bagi para pendengar dituntut untuk tampil meyakinkan. Untuk itu, unsur motivasi komunikasi harus melekat dalam diri seorang public speker agar menghindari kekhawatiran-kekhawatiran yang membuatnya ragu

\footnotetext{
9 http://id-blog.zenrooms.com/13-tips-agar-enjoy-maksimal-di-we-the-fest-2017-festival-musik-musim-panasterbesar-di-indonesia/
} 
dengan kemampuannya. Kemampuan Public speaking menjadi tuntutan hampir semua profesi guru, dosen, manejer, pendakwah, instruktur, narasumber, penyiar, presenter, mc/pembawa acara, politikus dan pembisnis sehingga seorang public speaker menjadi pemenang diatas panggung sebaiknya Ketenangan kesempurnaan persiapannya. Kemudian setiap proses pelaksanaanya dilakukan dengan sistematis.

Seseorang yang pandai berbicara adalah seseorang dapat menyampaikan topik secara jelas. Pembicara mengetahui siapa yang diajak berbicara agar dapat berbicara dengan baik dan benar serta berbicara harus urut dari urutan awal, tengah dan akhir. Pembicara harus menggunakan faktor psikis, psikologis dan neurologis dan linguistik dalam menyampaikan gagasannya. Setiap Pembicaraan yang kita sampaikan harus menggunakan konsep yang baik dari awal acara sampai akhir pembicaraan kita supaya orang lebih memahami apa yang sampaikan. Buat orang lain tertarik kepada topik pembicaraan, sampaikan pembicaraan dengan menggunakan bahasadan cara yang tepat dalam setiap acara dengan menyesuaikan situasi di mana kita berbicara. Menjadi seseorang mahir public speaking kepiawaian tentunya memerlukan keahlian yaitu mampu merangkai kata-kata sehingga indah didengar dan membius audiens dengan urgensi kemampuan berbicara di depan publik dapat menguasai semua forum serta menjadi pemenang diatas panggung.

\section{DAFTAR PUSTAKA}

Andrew, M. (2007). Mengembangkan Kepribadian dengan Berpikir Positif. Jakarta: Prestasi Pustakarya.

Balqis khairiyah, 2013.Cara pintar berbicara didepan publik, Jogjakarta :Diva press

Bayu krisna, 2008 mendulang rupia lewat kemampuan berbicara. Jakarta : Pt. Tangga pustaka Bewes, Richard. (2010). Effective Public Speaking. Jakarta: Pt BPK Gunung Mulia.Elly dan Pranama, J. (2006). General Public Speaking. Jakarta: Public Speaking School.

Juniarti, Elly dan Pramana. 2006. General Public Speaking. Jakarta: Public Speaking School Johanes arifin 2007. Public speaking is easy Jogjakarta : Cv andi.

Laryking, 2013 seni berbicara. Jakarta : Pt Gramedia

Novita kristi, 2013 Jurus kilat jago public speaking. Jakarta: Pt. Laskar askara

Maryanto, Bambang. 2007. Contoh-contoh MC dan Pidato. Surabaya : Apolo

McCarty, Andrew. 2007. Mengembangkan Kepribadian dengan Berpikir Positif. Jakarta : Romlatul

Hikmah, S.Hum, 2008 Terjemahan dari : How to positive thinking . Jakarta : penerjemah Prestasi Pustakakarya.

Sameto, Hudoro.1996. Kiat Sukses Mengolah Komunikasi. Jakarta : Puspa Sawara

Ongki Hojanto. (2012). Public Speaking Mastery. Jakarta: Pt Gramedia

REFERENSI LAIN :

http://id-blog.zenrooms.com/13-tips-agar-enjoy-maksimal-di-we-the-fest-2017-festivalmusik-musim-panas-terbesar-di-indonesia

http://www.romelteamedia.com/2013/11/5-cara-mempengaruhi-publik-dalam-public.html 